\title{
Thiacalix[4]monocrowns Substituted by Sulfur-Containing Anchoring Groups: New Ligands for Gold Surface Modification
}

\author{
Anton A. Muravev, ${ }^{a} @$ Svetlana E. Solovieva, ${ }^{a}$ Evgenii N. Kochetkov, ${ }^{\text {b }}$ \\ Nina B. Mel'nikova, ${ }^{b}$ Roman A. Safiullin, ${ }^{a}$ Marsil K. Kadirov, ${ }^{a}$ Shamil K. Latypov, ${ }^{a}$ \\ Igor S. Antipin, ${ }^{a, c}$ and Alexander I. Konovalov
}
Dedicated to Academician of the Russian Academy of Sciences A. I. Konovalov on the occasion of his $80^{\text {th }}$ birthday

\author{
${ }^{a}$ A.E. Arbuzov Institute of Organic and Physical Chemistry KazSC RAS, 420088 Kazan, Russia \\ ${ }^{\mathrm{b}}$ Nizhny Novgorod State Medical Academy, 603005 Nizhny Novgorod, Russia \\ ${ }^{\mathrm{C}}$ Kazan Federal University, 420008 Kazan, Russia \\ @Corresponding authorE-mail: antonm@iopc.ru
}

\begin{abstract}
Crown containing calix[4]arenes 2 a-f with thioacetate-functionalized carbon chains on lower rim in 1,3-alternate conformation were synthesized starting from corresponding bromo-derivatives. The use of thiacalixcrowns monolayer films improves adhesion between gold and biomolecules (cytochrome c and catalase). The structures of these monolayers were analyzed using contact angle measurements and AFM visualization by discontinuous contact mode.
\end{abstract}

Keywords: Thiacalix[4]monocrowns, thioacetates, LB films, gold surfaces, cytochrome $c$, catalase.

\section{Тиакаликс[4]монокрауны, замещенные серосодержащими якорными группами: новые лиганды Аля модификации золотой ПОАлОЖки}
A. A. Муравьев, ${ }^{\mathrm{a}}$
С. Е. Соловьева, ${ }^{a}$
Е. Н. Кочетков, ${ }^{\text {b }}$
Н. Б. Мельникова, ${ }^{\text {b }}$
P. А. Сафиуллин, ${ }^{a}$ M. К. Кадиров, ${ }^{a}$ Ш. К. Аатыпов, $^{a}$ И. С. Антипин, ${ }^{\text {a, }}$
А. И. Коновалов

Посвящается академику РАН А. И. Коновалову по случаю его 80-летнего юбилея

\author{
а Институт органической и физической химии им. А.Е. Арбузова Каз НЦ РАН, 420088 Казань, Россия \\ ${ }^{\mathrm{b}}$ Нижегородская государственная медиџинская академия, 603005 Нижний Новгород, Россия \\ 'Казанский федеральный университет, 420008 Казань, Россия \\ @E-mail: antonm@iopc.ru
}

\begin{abstract}
Синтезированы каликс[4]крауны 2a-f с алкокситиоацето-группами на нижнем ободе в конформации 1,3альтернат, исходя из соответствующих бром-производных. Показано, что использование монослоев тиакаликскраунов улучшает адгезию биомолекул (цитохрома с и каталазы) с золотой подложкой. Структура монослоев проанализирована методом смачивания и визуализирована методом АСМ.
\end{abstract}

Ключевые слова: Тиакаликс[4]крауны, тиоацетаты, ЛБ пленки, золотые подложки, цитохром $c$, каталаза. 


\section{Introduction}

The application of bioactive molecules to be employed as recognition elements in biosensors has stimulated researchers to develop new methods to their deposition on the solid surfaces, particularly, on gold. ${ }^{[1-3]}$ However, electrostatic physisorption of biomolecules (for example, cytochrome $c$ ) onto planar gold surface is not effective and has been shown to result in drastic changes in its conformation and often in denaturation of protein. ${ }^{[4,5]}$ Surface functionalization using a self-assembled monolayer (SAM) is of great importance for engineering biosensor devices, which use electrical current or UV-Vis absorption involving protein mediation. ${ }^{[6]}$ It plays a key role because of shedding absorbed biomolecules from the excessive electron density of the metal and binds targeting proteins through the establishment of complementary intermolecular interactions. Cytochrome $c$ and catalase have arrays of amino groups in its three-dimensional structure making these regions positively charged at neutral $\mathrm{pH}$. In this sense, new thiacalixcrown derivatives containing anchoring groups on lower rim were synthesized and their ability to form monolayers with cytochrome $c$ and catalase on water and gold surfaces was investigated.

\section{Experimental}

\section{Materials and Analytical Measurements}

Potassium thioacetate and hydrazine monohydrate were purchased from Acros and used as received. Solvents were purified according to known procedures. ${ }^{[7]}$ Compounds 1a-f, 2b and $\mathbf{5}$ were synthesized as in ${ }^{[8,9]}$, correspondingly. Their constants were consistent with those published in ${ }^{[8,9]}$. All reactions were performed in argon atmosphere. NMR spectra were recorded on Bruker Avance-400 $\left({ }^{1} \mathrm{H}\right)$ and $600\left({ }^{13} \mathrm{C}\right.$ and $2 \mathrm{D}$ experiments) spectrometers relative to the signals of residual protons of deuterated solvents $\left(\mathrm{CDCl}_{3}\right)$. Bruker Vector 22 Fourier spectrometer was used to record IR spectra in the wavenumber range of $400-4000 \mathrm{~cm}^{-1}$ in $\mathrm{KBr}$ pellets or nujol. MALDI TOF mass spectra were recorded from the solutions of substances on a Bruker Ultraflex III mass-spectrometer in the concentration range of $10^{-3}-10^{-5} \mathrm{M}$ (matrices are $p$-nitroaniline ( $p$-NA) and 2,5-dihydroxybenzoic acid (DHB)). Elemental analysis was performed on a $\mathrm{CHN}$-analyzer via combustion of sample; melting point was measured on a Boetius compact heating table. Numbering of carbon atoms for compounds $\mathbf{3}$ and $\mathbf{6}$ is given in Figure 1 and Scheme 4, respectively.

Langmuir film experiments were provided with Nima LB Deposition Trough 112D (KSV Nima, Sweden) system using deionized water (resistivity $>18 \mathrm{M} \Omega \mathrm{cm}$, Simplicity, Millipore Inc.) with $5.5 \mathrm{pH}$ at $20 \pm 1^{\circ} \mathrm{C}$. For registration of the surface pressure-area $(\pi-\mathrm{A})$ isotherms the Wilhelmy plate method was used. Spreading time and compression speed were chosen to provide as low hysteresis of the films as possible. Compression of the film was provided in continuous mode at a speed rate $60 \mathrm{~cm}^{2} \cdot \mathrm{min}^{-1}$ by two symmetric frames. Spreading solutions were prepared by dissolving the appropriate amount of $\mathbf{2} \mathbf{f}$ in chloroform at a concentration 0.5 $\mathrm{mg} \cdot \mathrm{ml}^{-1} .10 \mu \mathrm{L}$ of this solution were spread on the aqueous subphase with a microsyringe in several stages; 30-40 min was allowed for evaporation of the solvent and equilibration of the amphiphiles on the interface. $1.05 \cdot 10^{-8} \mathrm{~mol}$ of $\mathbf{2} \mathbf{f}$ was spread on the subphase surface. Langmuir-Schaefer ${ }^{[10]}$ technique was used to deposit monolayers on gold substrate at a surface tension $\pi=30 \mathrm{mN} \cdot \mathrm{m}^{-1}$. The transferred films were rinsed by deionized water and then were dried in vacuum during 8 hours.

Visualization of the film of compound $2 \mathbf{f}$ was made according to atomic force microscopy with the use of a MultiMode V ("Veeco") scanning probe microscope. The samples were transferred to gold surface that was sprayed on crystal silica ("Aldrich"). Gold surface was initially degreased with alcohol and washed with deionized water overnight. The plates were dried at $130{ }^{\circ} \mathrm{C}$ for $3 \mathrm{~h}$. Weight concentrations of catalase and cytochrome $c$ in water subphase are $0.01 \mathrm{~g} / \mathrm{L}$.

5,11,17,23-Tetra-tert-butyl-25-acetyloxy-27-hydroxy2,8,14,20-tetrathiacalix[4]arene-monocrown-3 (7). $0.24 \mathrm{~g}(0.24$ $\mathrm{mmol})$ of thiacalixcrown 3 and $0.11 \mathrm{~g}(0.96 \mathrm{mmol})$ of potassium thioacetate were stirred in $10 \mathrm{~mL}$ of DMF for $3 \mathrm{~h}$ at $90{ }^{\circ} \mathrm{C} .10 \mathrm{~mL}$ of water were added to a cooled mixture and residue was extracted with $30 \mathrm{~mL}$ chloroform and washed with water $(10 \mathrm{~mL})$; organic phase was dried over $\mathrm{MgSO}_{4}$ and solvent was removed under vacuum. Methanol was added to residue $(5 \mathrm{~mL})$, precipitate was filtered and dried to give $7(0.04$ g, $16 \%)$, m.p. $208{ }^{\circ} \mathrm{C}, R_{\mathrm{f}}(\mathrm{Hex}: \mathrm{EtOAc}=9: 1)$ 0.46. Found: $\mathrm{C} 62.27, \mathrm{H} 6.56 \% ; \mathrm{C}_{46} \mathrm{H}_{56} \mathrm{O}_{6} \mathrm{~S}_{4} \cdot 3 \mathrm{H}_{2} \mathrm{O}$ requires $\mathrm{C} 62.27$, $\mathrm{H}$ 7.04. $\mathrm{m} / \mathrm{z}(\mathrm{DHB}) 833.2\left[\mathrm{M}^{+}\right], 856.2\left[(\mathrm{M}+\mathrm{Na})^{+}\right], 873.1\left[(\mathrm{M}+\mathrm{K})^{+}\right]$. IR (KBr) $v_{\text {max }} \mathrm{cm}^{-1}: 1763 \mathrm{~s}(\mathrm{C}=\mathrm{O}) .{ }^{1} \mathrm{H}$ NMR $\left(\mathrm{CDCl}_{3}, 400 \mathrm{MHz}, 303\right.$ K) $\delta_{\mathrm{H}}$ ppm: $7.79(2 \mathrm{H}, \mathrm{AB}-\mathrm{d}, 3), 7.76(2 \mathrm{H}, \mathrm{AB}-\mathrm{d}, 3), 7.51(1 \mathrm{H}, \mathrm{s}$, $\mathrm{OH}), 7.26(2 \mathrm{H}, \mathrm{s}, 9), 6.39(2 \mathrm{H}, \mathrm{s}, 13), 4.99$ (4H, t $\left.J=9.4 \mathrm{~Hz}, 5_{\mathrm{ax}}\right)$, $4.47\left(4 \mathrm{H}, \mathrm{t} J=8.8 \mathrm{~Hz}, 6_{\mathrm{ax}}\right), 4.21\left(4 \mathrm{H}, \mathrm{t} J=8.8 \mathrm{~Hz}, 6_{\mathrm{eq}}\right), 3.96(4 \mathrm{H}$, t $J=9.4 \mathrm{~Hz}, 5$ eq $), 2.53(3 \mathrm{H}, \mathrm{s}, 16), 1.36(18 \mathrm{H}, \mathrm{s}, 4 \mathrm{~b}), 1.06(9 \mathrm{H}, \mathrm{s}$, 10b), 0.51 (9H, s, 14b). ${ }^{13} \mathrm{C} \mathrm{NMR}\left(\mathrm{CDCl}_{3}, 150.92 \mathrm{MHz}, 303 \mathrm{~K}\right) \delta_{\mathrm{C}}$ ppm: 168.77 (15i), 159.97 (1i), 156.26 (7i), 147.91 (14i), 147.49 (4i), 145.74 (11i), 144.13 (10i), 136.00 (3), 135.51 (3'), 134.88 (9), 131.76 (2i'), 131.08 (2i), 129.77 (12i), 129.37 (13), 125.60 (8i), 72.04 (5), 71.22 (6), 34.50 (4a), 34.00 (10a), 33.72 (14a), 31.40 (4b), 31.01 (10b), 30.63 (14b), 20.95 (16).

5,11,17,23-Tetra-tert-butyl-25,27-dihydroxy-2,8,14,20tetrathiacalix[4]arene-monocrown-3 (4). Thiacalixcrown $\mathbf{2 a}$ $(0.10 \mathrm{~g}, 0.10 \mathrm{mmol})$ and $10 \mathrm{~mL}$ of hydrazine hydrate were stirred for $30 \mathrm{~h}$ at $110{ }^{\circ} \mathrm{C}$. Precipitate was filtered; washed with $10 \mathrm{~mL}$ of $0.1 \mathrm{~N} \mathrm{HCl}$ and water $(15 \mathrm{~mL})$ to neutral reaction, and $10 \mathrm{~mL}$ of methanol; and dried to give compound $6(0.069 \mathrm{~g}, 87 \%)$, m.p. $251^{\circ} \mathrm{C}, R_{\mathrm{f}}(\mathrm{Hex}: \mathrm{EtOAc}=4: 1)$ 0.51. $\mathrm{m} / z$ ( $p$-NA) $792.0\left[\mathrm{M}^{+}\right], 815.1$ $\left[(\mathrm{M}+\mathrm{Na})^{+}\right], 829.6\left[(\mathrm{M}+\mathrm{K})^{+}\right]$. IR (nujol) $v_{\max } \mathrm{cm}^{-1}: 3436 \mathrm{w}(\mathrm{OH}) .{ }^{1} \mathrm{H}$ NMR $\left(\mathrm{CDCl}_{3}, 400 \mathrm{MHz}, 303 \mathrm{~K}\right) \delta_{\mathrm{H}} \mathrm{ppm:} 7.78(4 \mathrm{H}, \mathrm{s}, 3), 7.42(2 \mathrm{H}$, s, OH), $6.90(4 \mathrm{H}, \mathrm{s}, 9), 4.65(4 \mathrm{H}, \mathrm{t} J=4.5 \mathrm{~Hz}, 5), 4.28(4 \mathrm{H}, \mathrm{t} J=4.4$ $\mathrm{Hz}, 6), 1.36(18 \mathrm{H}, \mathrm{s}, t-\mathrm{Bu}), 0.84(18 \mathrm{H}, \mathrm{s}, t-\mathrm{Bu})$.

General procedure of synthesis of thioacetates 4-6. In a 15$\mathrm{mL}$ round-bottom flask, thiacalixcrowns $1(0.54 \mathrm{mmol})$ and 0.12 $\mathrm{g}$ of potassium thioacetate $(1.07 \mathrm{mmol})$ were suspended in 10 $\mathrm{mL}$ of DMF and heated at stirring with reflux condenser; at $80{ }^{\circ} \mathrm{C}$ suspension became light-yellow. The mixture was heated for $3 \mathrm{~h}$ at $90{ }^{\circ} \mathrm{C}$ (progress of reaction was monitored by TLC in hexane:ethyl acetate $=9: 1$ eluent). The reaction mixture was removed from solvent and residue was treated with methanol $(10 \mathrm{~mL})$ to give the precipitate, which was further filtered.

5,11,17,23-Tetra-tert-butyl-25,27-di(2-thioacetoethoxy)2,8,14,20-tetrathiacalix[4]arene-monocrown-3 (2a). 83 \%, m.p. $279{ }^{\circ} \mathrm{C}$ (decomp.), $R_{\mathrm{f}}$ (Hex:EtOAc $\left.=8: 1\right)$ 0.61. Found: C 57.85, H $6.37 \% ; \mathrm{C}_{48} \mathrm{H}_{60} \mathrm{O}_{5} \mathrm{~S}_{4} \mathrm{Br}_{2} \cdot 2\left(\mathrm{CH}_{3}\right)_{2} \mathrm{C}(\mathrm{O})$ requires $\mathrm{C} 57.85, \mathrm{H} 6.47 . \mathrm{m} / \mathrm{z}$ (DHB) (\%) $1027(100)\left[(\mathrm{M}+\mathrm{Na})^{+}\right]$. IR (nujol) $v_{\max } \mathrm{cm}^{-1}: 1701 \mathrm{~s}$ $(\mathrm{C}=\mathrm{O}) .{ }^{1} \mathrm{H} \mathrm{NMR}\left(\mathrm{CDCl}_{3}, 400 \mathrm{MHz}, 303 \mathrm{~K}\right) \delta_{\mathrm{H}} \mathrm{ppm}: 7.50(4 \mathrm{H}, \mathrm{s}$, $\left.\mathrm{H}_{\text {arom }}\right), 7.31\left(4 \mathrm{H}, \mathrm{s}, \mathrm{H}_{\text {arom }}\right), 3.91\left(4 \mathrm{H}, \mathrm{t} J=7.8 \mathrm{~Hz}, \mathrm{OCH}_{2} \mathrm{CH}_{2} \mathrm{Br}\right), 3.58$ $\left(4 \mathrm{H}, \mathrm{t} J=5.4 \mathrm{~Hz}, \mathrm{OCH}_{2} \mathrm{CH}_{2} \mathrm{O}\right), 2.76\left(4 \mathrm{H}, \mathrm{t} J=5.5 \mathrm{~Hz}, \mathrm{OCH}_{2} \mathrm{CH}_{2} \mathrm{O}\right)$, $2.38\left(4 \mathrm{H}, \mathrm{t} J=7.8 \mathrm{~Hz}, \mathrm{CH}_{2} \mathrm{~S}\right), 2.26(6 \mathrm{H}, \mathrm{s}, \mathrm{Me}), 1.29(18 \mathrm{H}, \mathrm{s}, t-\mathrm{Bu})$, $1.28(18 \mathrm{H}, \mathrm{s}, t-\mathrm{Bu})$.

5,11,17,23-Tetra-tert-butyl-25,27-di(2-thioacetoethoxy)2,8,14,20-tetrathiacalix[4]arene-monocrown-4 (2c). $85 \%$, m.p. $276{ }^{\circ} \mathrm{C}, R_{\mathrm{f}}$ (Hex:EtOAc=9:1) 0.46. Found: C 62.37, H 6.79 $\% ; \mathrm{C}_{54} \mathrm{H}_{70} \mathrm{O}_{8} \mathrm{~S}_{6}$ requires $\mathrm{C}$ 62.39, H 5.36. $\mathrm{m} / \mathrm{z}$ (DHB) 1061.73 $\left[(\mathrm{M}+\mathrm{Na})^{+}\right], 1077.77\left[(\mathrm{M}+\mathrm{K})^{+}\right] . \mathrm{IR}(\mathrm{KBr}) v_{\max } \mathrm{cm}^{-1}: 1698 \mathrm{~s}(\mathrm{C}=\mathrm{O})$. 
${ }^{1} \mathrm{H}$ NMR $\left(\mathrm{CDCl}_{3}, 400 \mathrm{MHz}, 303 \mathrm{~K}\right) \delta_{\mathrm{H}} \mathrm{ppm:} 7.55\left(4 \mathrm{H}, \mathrm{s}, \mathrm{H}_{\text {arom }}\right)$, $7.32\left(4 \mathrm{H}, \mathrm{s}, \mathrm{H}_{\text {arom }}\right), 4.03\left(4 \mathrm{H}\right.$, br s, $\left.\mathrm{ArOCH}_{2} \mathrm{CH}_{2} \mathrm{O}\right), 3.94$ (4H, t $J=8.3$ $\left.\mathrm{Hz}, \mathrm{OCH}_{2} \mathrm{CH}_{2} \mathrm{SAc}\right), 3.51\left(4 \mathrm{H}\right.$, br s, $\left.\mathrm{ArOCH}_{2} \mathrm{CH}_{2} \mathrm{O}\right), 2.34(4 \mathrm{H}, \mathrm{t}$ $\left.J=8.4 \mathrm{~Hz}, \mathrm{OCH}_{2} \mathrm{CH}_{2} \mathrm{SAc}\right), 2.29\left(6 \mathrm{H}, \mathrm{s}, \mathrm{CH}_{3}\right), 1.31(18 \mathrm{H}, \mathrm{s}, t-\mathrm{Bu})$, $1.26(\mathrm{~s}, 18 \mathrm{H}, t-\mathrm{Bu})$.

5,11,17,23-Tetra-tert-butyl-25,27-di(3-thioacetopropoxy)2,8,14,20-tetrathiacalix[4] arene-monocrown-4 (2d). Yield $91 \%$, m.p. $275{ }^{0} \mathrm{C}, R_{\mathrm{f}}$ (Hex:EtOAc=8:1) 0.48. $\mathrm{m} / \mathrm{z}$ (DHB) 1089.51 $\left[(\mathrm{M}+\mathrm{Na})^{+}\right], 1105.52\left[(\mathrm{M}+\mathrm{K})^{+}\right] .{ }^{1} \mathrm{H}$ NMR $\left(\mathrm{CDCl}_{3}, 400 \mathrm{MHz}, 303 \mathrm{~K}\right)$ $\delta_{\mathrm{H}}$ ppm: $7.37\left(4 \mathrm{H}, \mathrm{s}, \mathrm{H}_{\text {arom }}\right), 7.32\left(4 \mathrm{H}, \mathrm{s}, \mathrm{H}_{\text {arom }}\right), 3.98(4 \mathrm{H}, \mathrm{t} J=4.1 \mathrm{~Hz}$, $\left.\mathrm{OCH}_{2} \mathrm{CH}_{2} \mathrm{O}\right), 3.85\left(4 \mathrm{H}, \mathrm{t} J=7.8 \mathrm{~Hz}, \mathrm{ArOCH}_{2}\right), 3.47(4 \mathrm{H}, \mathrm{t} J=3.9 \mathrm{~Hz}$, $\left.\mathrm{OCH}_{2} \mathrm{CH}_{2} \mathrm{O}\right), 2.71\left(4 \mathrm{H}, \mathrm{t} J=7.3 \mathrm{~Hz}, \mathrm{CH}_{2} \mathrm{Br}\right), 2.52(6 \mathrm{H}, \mathrm{s}, \mathrm{Me}), 1.31$ $(18 \mathrm{H}, \mathrm{s}, t-\mathrm{Bu}), 1.27(18 \mathrm{H}, \mathrm{s}, t-\mathrm{Bu})$.

5,11,17,23-Tetra-tert-butyl-25,27-di(2-thioacetoethoxy)2,8,14,20-tetrathiacalix[4]arene-monocrown-5 (2e). 81\%, m.p. $284{ }^{\circ} \mathrm{C}, R_{\mathrm{f}}$ (Hex:EtOAc=4:1) 0.40, $R_{\mathrm{f}}($ Hex:EtOAc=9:1) 0.26 . Found: $\mathrm{C} 62.27, \mathrm{H} 6.56 \%$; $\mathrm{C}_{54} \mathrm{H}_{70} \mathrm{O}_{7} \mathrm{~S}_{6} \cdot \mathrm{H}_{2} \mathrm{O}$ requires $\mathrm{C} 62.27, \mathrm{H}$ 6.97. $\mathrm{m} / z(\mathrm{DHB}) 1106.2\left[(\mathrm{M}+\mathrm{Na})^{+}\right], 1122.2\left[(\mathrm{M}+\mathrm{K})^{+}\right]$. IR (nujol) $v_{\max } \mathrm{cm}^{-1}: 1684 \mathrm{~s}(\mathrm{C}=\mathrm{O}) .{ }^{1} \mathrm{H}$ NMR $\left(\mathrm{CDCl}_{3}, 400 \mathrm{MHz}, 303 \mathrm{~K}\right) \delta_{\mathrm{H}}$ ppm: $7.44\left(4 \mathrm{H}, \mathrm{s}, \mathrm{H}_{\text {arom }}\right), 7.34\left(4 \mathrm{H}, \mathrm{s}, \mathrm{H}_{\text {arom }}\right), 3.94(4 \mathrm{H}, \mathrm{t} J=8.0 \mathrm{~Hz})$, $3.92(4 \mathrm{H}, \mathrm{t} J=8.0 \mathrm{~Hz}), 3.59(4 \mathrm{H}, \mathrm{t} J=3.7 \mathrm{~Hz}), 3.37(4 \mathrm{H}, \mathrm{t} J=3.7 \mathrm{~Hz})$, $2.99(4 \mathrm{H}, \mathrm{t} J=8.4 \mathrm{~Hz}), 2.29(4 \mathrm{H}, \mathrm{t} J=8.2 \mathrm{~Hz}), 2.26\left(6 \mathrm{H}, \mathrm{s}, \mathrm{CH}_{3}\right), 1.35$ $(18 \mathrm{H}, \mathrm{s}, t-\mathrm{Bu}), 1.26(18 \mathrm{H}, \mathrm{s}, t-\mathrm{Bu})$.

5,11,17,23-Tetra-tert-butyl-25,27-di(3-thioacetopropoxy)2,8,14,20-tetrathiacalix[4]arene-monocrown-5 (2f). $80 \%$, m.p. $298{ }^{\circ} \mathrm{C}, R_{\mathrm{f}}$ (Hex:EtOAc=9:1) 0.31. Found: C 63.42, H 5.44 $\% ; \mathrm{C}_{58} \mathrm{H}_{78} \mathrm{O}_{9} \mathrm{~S}_{6}$ requires C 62.67, $\mathrm{H}$ 7.07. $\mathrm{m} / \mathrm{z}$ (DHB) 984.04 $\left[(\mathrm{M}-\mathrm{SAc}+\mathrm{K})^{+}\right], 1134.53\left[(\mathrm{M}+\mathrm{Na})^{+}\right], 1149.46\left[(\mathrm{M}+\mathrm{K})^{+}\right] . \mathrm{IR}$ (nujol) $v_{\max } \mathrm{cm}^{-1}: 1686 \mathrm{~s}(\mathrm{C}=\mathrm{O}) .{ }^{1} \mathrm{H} \mathrm{NMR}\left(\mathrm{CDCl}_{3}, 400 \mathrm{MHz}, 303 \mathrm{~K}\right) \delta_{\mathrm{H}}$ ppm: $7.36\left(4 \mathrm{H}, \mathrm{s}, \mathrm{H}_{\text {arom }}\right), 7.28\left(4 \mathrm{H}, \mathrm{s}, \mathrm{H}_{\text {arom }}\right), 3.94(4 \mathrm{H}, \mathrm{t} J=8.0 \mathrm{~Hz})$, $3.87(8 \mathrm{H}, \mathrm{m}), 3.60(4 \mathrm{H}, \mathrm{br} \mathrm{s}), 3.37(4 \mathrm{H}, \mathrm{br} \mathrm{s}), 2.95(4 \mathrm{H}, \mathrm{t} J=8.0 \mathrm{~Hz})$, $2.62(4 \mathrm{H}, \mathrm{t} J=7.0 \mathrm{~Hz}), 2.31\left(6 \mathrm{H}, \mathrm{s}, \mathrm{CH}_{3}\right), 1.35(18 \mathrm{H}, \mathrm{s}, t-\mathrm{Bu}), 1.27$ $(18 \mathrm{H}, \mathrm{s}, t-\mathrm{Bu}), 1.15(4 \mathrm{H}, \mathrm{m} J=7.2 \mathrm{~Hz})$.

\section{Results and Discussion}

Thiacalix[4]arene in 1,3-alternate configuration (Scheme 1) is a very promising molecular platform for the design of new types of nanosized conjugate ${ }^{[8,9,11-13]}$ consist of structural moieties with different properties. In this publication thiacalixarenes $\mathbf{2}$ which combine together recognition and anchoring functions is described.

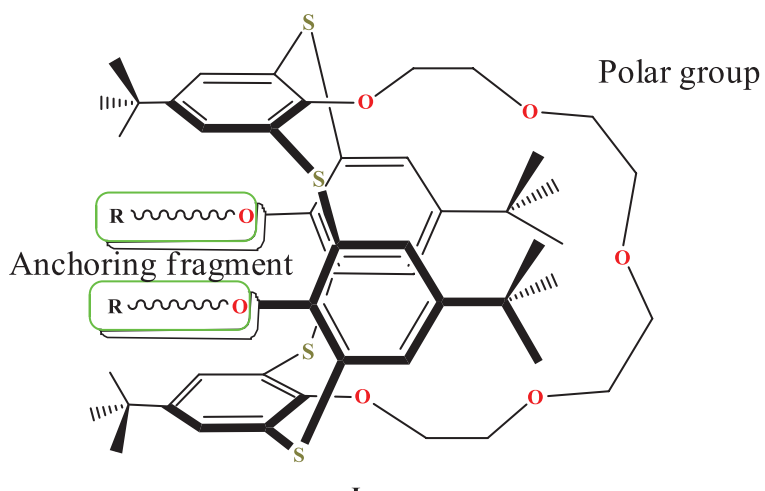

I

Scheme 1.

Well known that crown ethers form with ammonium group very stable host-guest complexes based on the $\mathrm{N}-\mathrm{H} \cdots \mathrm{O}$ hydrogen-bond interactions. ${ }^{[14-16]}$ On other hand, gold surfaces have a high affinity for sulfur containing compounds: thiols (RSH), sulfides ( $\left.\mathrm{R}_{2} \mathrm{~S}\right)$, disulfides $\left(\mathrm{R}_{2} \mathrm{~S}_{2}\right)$, and thioacetates $(\mathrm{RSC}(\mathrm{O}) \mathrm{R}) \cdot{ }^{[17-19]}$ For these reasons, thiacalixarene derivatives
(Scheme 1) containing crown-ether fragment for the binding of positively charged parts of biomolecules, on one side of macrocycle, and anchoring thioacetate groups for the immobilization on a solid substrate, on other side, has been designed.

Thioaceto-substituted monocrowns 2a-f were obtained from bromo-substituted derivatives $\mathbf{1 a - \mathbf { f } ^ { [ 9 ] }}$ using the stoichiometric thiacalixarene-to-potassium thioacetate ratio of 1:2 (Scheme 2) with high yields (80-90\%) according to the method that was developed by us earlier for tetrasubstituted thiacalixarene derivatives. ${ }^{[20]}$
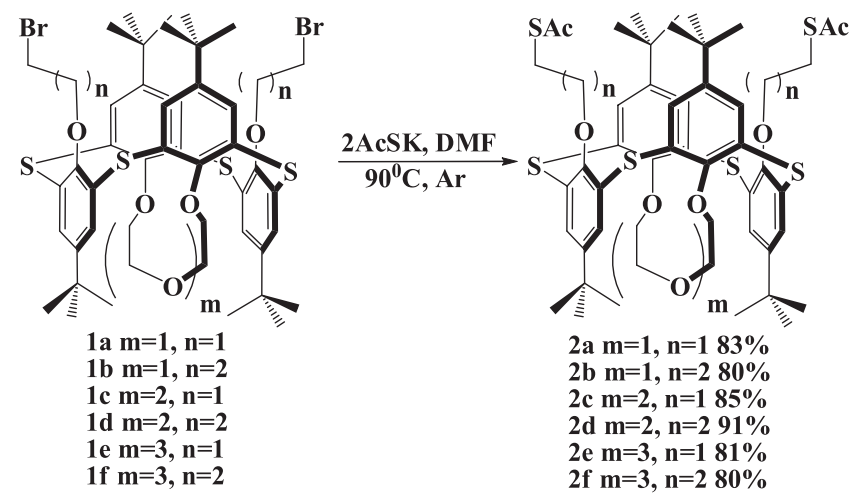

Scheme 2.

It was determined that the increase of excess of potassium thioacetate in the reaction mixture does not influence the yield of most products. When compound 1a is used, fourfold excess of potassium thioacetate leads to the cleavage of two substituents on the lower rim of thiacalixarene and the mixture of dealkylation products is formed. Among them trisubstituted thiacalix[4]monocrown-3 $\mathbf{3}$ in cone stereoisomeric form with one acetyl group was isolated with $16 \%$ yield (Scheme 3 ).
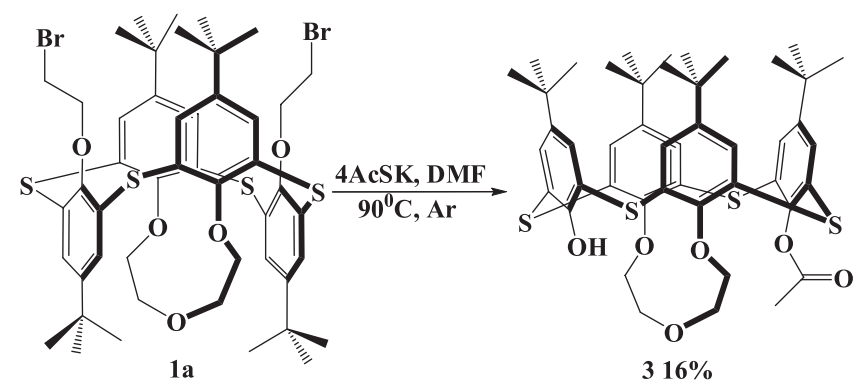

Scheme 3

With an aim to establish structure of this macrocycle, a series of NMR experiments was performed. In 1D DPFGNOE spectrum (Figure 1), both interaction of aromatic groups with tert-butyl fragments (3 and 3' with 4b, 13 with $14 \mathrm{~b}$ and 9 with $10 \mathrm{~b}$ ) and each other (3 with 13 and 3 ' with 9) and interaction of crown-ether fragments, 5 and 6, with acetyl fragment 16 and hydroxyl group were observed. From the other side, interaction of crown-ether fragments with aromatic or tert-butyl groups, which is intrinsic for 1,3-alternate stereoisomeric form, was not observed. Assuming the multiplicity of aromatic and tert-butyl groups in calixarene scaffold, this method allows the assignment of cone stereoisomeric form for the product obtained. 

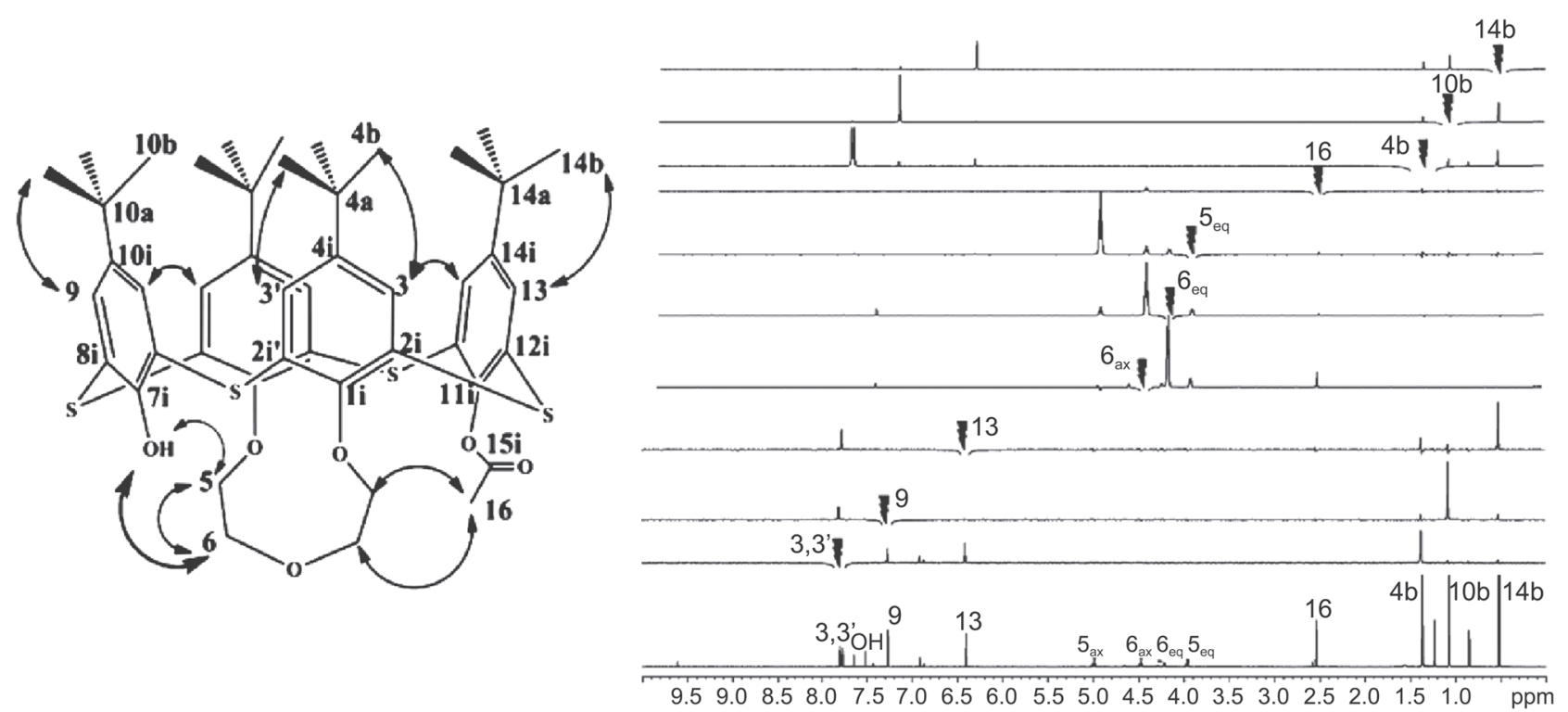

Figure 1. 1D NOE spectrum of compound 3 (right) and corresponding NOEs, which are indicated by arrows (left).
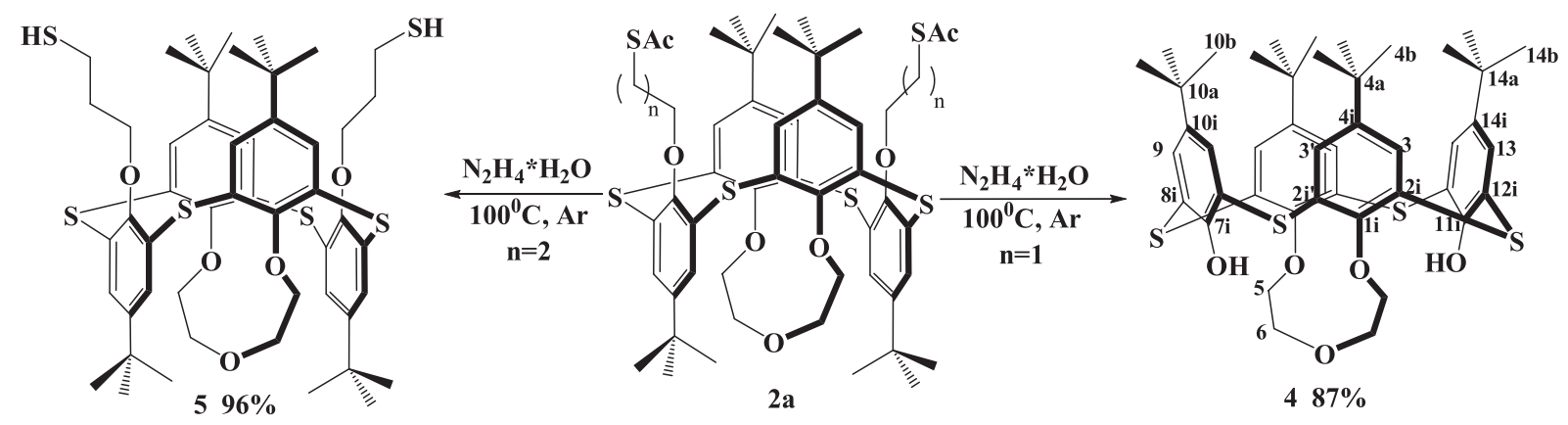

Scheme 4.

The second problem, which relates to the structure of acetate 3 , concerns the nature of heteroatom between aromatic ring and acetyl group (O or $\mathrm{S})$. GIAO DFT calculation of ${ }^{13} \mathrm{C}$ chemical shifts of closely located carbon atoms (11i, 15i, and 16) was done (Table 1). It was found that calculated chemical shifts of above-mentioned carbon atoms are close to experimental values for acetate substituent and this proves that benzene ring in calixarene molecule is linked to oxygen atom.

Table 1. GIAO DFT calculations of chemical shifts of ${ }^{13} \mathrm{C}$ atoms for two possible structures of $\mathbf{3}$ and experimental data.

\begin{tabular}{cccc}
\hline \multirow{2}{*}{$\begin{array}{c}\text { Carbon } \\
\text { atom }\end{array}$} & \multicolumn{2}{c}{ calculated for $\mathrm{ArXC}(\mathrm{O}) \mathrm{CH}_{3}$ fragment } & Experiment \\
\cline { 2 - 3 } & $\mathrm{X}=\mathrm{O}$ & $\mathrm{X}=\mathrm{S}$ & \\
\hline $15 \mathrm{i}$ & 169 & 193.2 & 168.8 \\
16 & 20.3 & 30.1 & 20.9 \\
$11 \mathrm{i}$ & 155 & 134.4 & 145.7 \\
\hline
\end{tabular}

Additional evidence of hydrolytic instability of compound $\mathbf{2 a}$ in basic media came from the investigation of hydrazinolysis. Reaction of $\mathbf{2 a}$ with hydrazine hydrate gave hydrolysis product - earlier unknown thiacalix[4] monocrown-3 4 in cone conformation with the yield of $87 \%$. It is important that thiacalixcrown-3 4 cannot be obtained directly from thiacalix[4] arene by the reaction with diethylene glycolderivatives (bromides, tosylates), because the formation of 1,2-crosslinked product or bisthiacalixarene is more preferable. ${ }^{[21]}$ In the case of 3-thioacetopropoxythiacalix[4] monocrown-3 2 b corresponding bis-thiol 5 was synthesized ${ }^{[9]}$ with high yield (96\%) (Scheme 4).

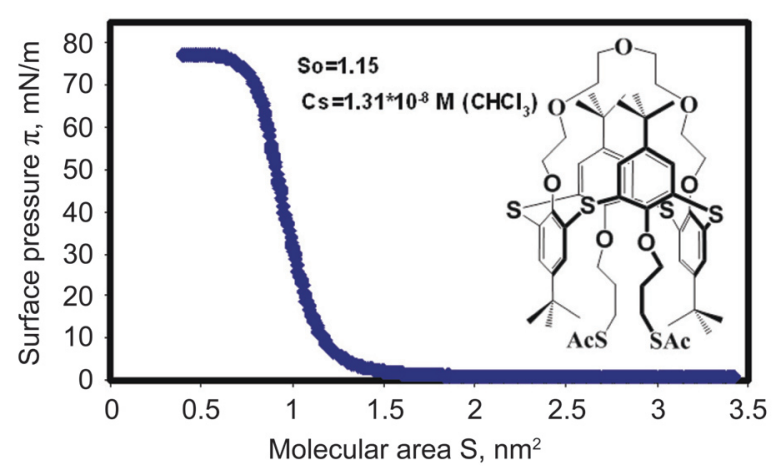

Figure 2. Compression isotherm $\pi=f(\mathrm{~S})$ of compound $\mathbf{2} \mathbf{f}$ on waterair interface. 
Table 2. Contact angles of gold surfaces modified by monolayers of $\mathbf{2 f}$.

\begin{tabular}{cccc}
\hline Number of monolayers & Subphase & Contact angle (deg.) & Error (deg.) \\
\hline 0 & - & 75.4 & 1.0 \\
1 & water & 82.7 & 0.4 \\
5 & water & 84.0 & 0.1 \\
1 & water + cytochrome $c^{*}$ & 81.7 & 1.6 \\
5 & water + cytochrome $c^{*}$ & 79.5 & 0.7 \\
1 & water + catalase** & 60.2 & 1.0 \\
5 & water + catalase** & 71.0 & 1.2 \\
\hline
\end{tabular}

$* 0.01 \mathrm{~g} / \mathrm{L}$ cytochrome $c ; * 0.01 \mathrm{~g} / \mathrm{L}$ catalase

The amphiphilic properties of the synthesized macrocycle $\mathbf{2 f}$ in 1,3-alternate conformation were studied using Langmuir balance technique. The compression isotherm show that the calixarene $\mathbf{2} \mathbf{f}$ forms stable and rigid $\left(\beta=2.0 \cdot 10^{-17} \mathrm{~N} / \mathrm{m}^{3}\right)$ Langmuir monolayers on water-air interface with the molecular area of $1.15 \mathrm{~nm}^{2} \cdot$ molecule $^{-1}$ (Figure 2). It is in good agreement with the calculated $\left(1.4 \mathrm{~nm}^{2} \cdot\right.$ molecule $\left.^{-1}\right)$ for calix[4]arene's monolayers with perpendicular orientation of macrocycle relative to waterair interface ${ }^{[22]}$ and experimental determined values $1.05,{ }^{[23]}$ $1.30^{[24]}$ and $1.11^{[25]} \mathrm{nm}^{2} \cdot$ molecule $^{-1}$.

The prepared monolayers of compound $\mathbf{2} \mathbf{f}$ on water-air interface were transferred to gold substrate by LangmuirSchaefer technique. In order to estimate the changes of surface energy during film formation on gold, contact angle measurement of water droplets was performed. The measured data are summarized in Table 2.

The consistent increase of transferred monolayers of $\mathbf{2} \mathbf{f}$ (from 1 to 5) leads to the gradual changes of surface hydrophobicity. As anticipated, the thiacalixarene deposition on gold increases the surface hydrophobicity; contact angle grows from $75.4^{\circ}$ to $84^{\circ}$. On the other hand, more significant changes occur at the transfer of initial monolayer. Subsequent transfers do not practically affect the wettability of modified surface. This can be related by the formation of continuous film on the gold at the transfer of the first monolayer.

The hydrophobicity of the films that were obtained in the presence of cytochrome $c$ and catalase in subphase differs significantly from those previously discussed. Incorporation of biomolecules into film decreases surface hydrophobicity, particularly, in the case of catalase. So, we can state that rather huge biomolecule such as cytochrome $c$ and catalase can be immobilized onto films formed by thiacalixarene $\mathbf{2 f}$ on the gold surface.

Additional evidences of continuous film formation with immobilized biomolecules were obtained by AFM visualization method. AFM images are given in Figure 3a-d. It is important to note that morphology of initial and modified gold surface doesn't significantly change. The films formed by calixcrown $\mathbf{2 f}$ with cytochrome $c$ and catalase (Figure 3b,c) practically repeat of substrate surface (Figure 3a), although the cross-section sizes of humps increase up to $100 \mathrm{~nm}(\sim 50$ $\mathrm{nm}$ for gold). It presumably confirms the strong interaction of calixarene derivatives 2 with gold. To prove the continu-

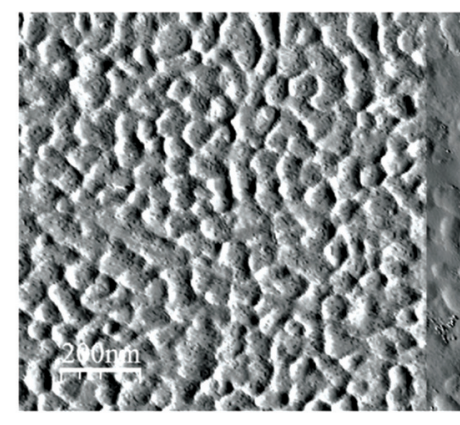

a)

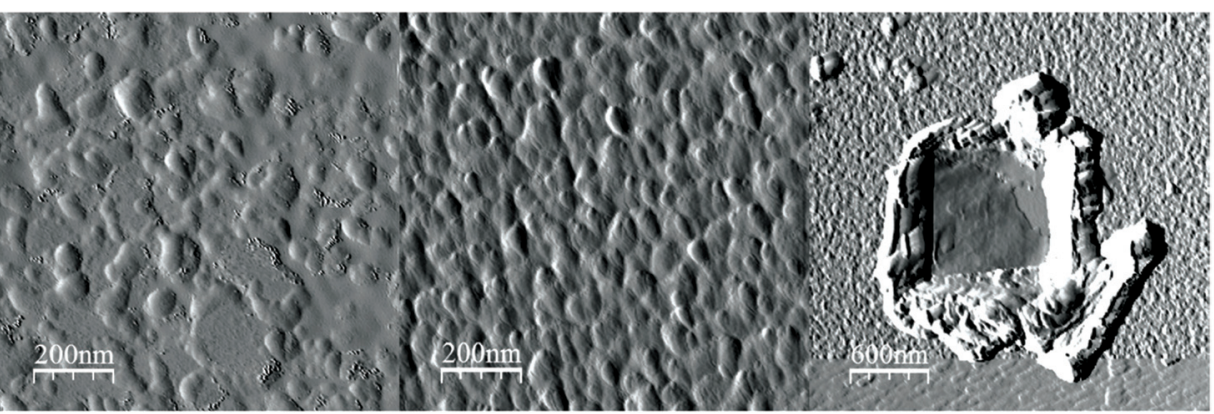

b)

c)

d)

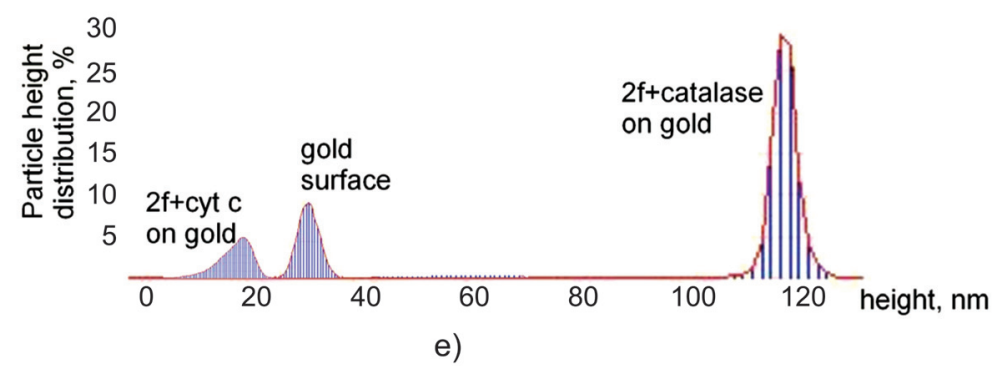

Figure 3. AFM image of (a) gold surface and (b-d) 5 transferred monolayers of $\mathbf{2 f}$ : (b) from aqueous solution of cytochrome $c$, (c) from aqueous solution of catalase, (d) from aqueous solution of catalase after removal of the part of film by cantilever tip; (e) particle height distributions $(5 \times 5 \mu \mathrm{m})$. 
ous film formation, the scratch-and-scan method was used. It comprises the removal of a small part of the film and subsequent imaging of the surface with a scanning-probe AFM (Figure 3d).

Analysis of the particle height distributions (Figure 3e) has shown that surface roughness strongly depends on the nature of immobilized molecules. Deposition of thiacalixcrown $2 \mathbf{f}$ with small protein - cytochrome $c(\sim 12 \mathrm{kDa})$, slightly decreases the roughness of gold surface up to $20 \mathrm{~nm}$. This fact may be caused by more effective filling of surface irregularities with cytochrome $c$. But the incorporation of huge biomolecule - catalase $(\sim 250 \mathrm{kDa})$, into the film leads to the substantial growth of the roughness of surface $(\sim 120 \mathrm{~nm})$.

\section{Conclusions}

New type of ligands on the basis of thiacalix[4]arene platform in 1,3-alternate conformation was designed for the functionalization of gold planar surface. It contains crown-ether fragment for the binding of positively charged parts of biomolecules, on one side of macrocycle, and anchoring thioacetate groups for the immobilization on a solid substrate, on other side. Contact angle measurements and AFM visualization provide evidence of the formation of continuous film with immobilized biomolecules on the gold surface.

Acknowledgements. The work was supported by RFBR grant no. 12-03-97085.

\section{References}

1. Evtugyn G.A. Biosensors: Essentials, Dordrecht: Springer, 2013.

2. Zhang X., Tretjakov A., Hovestaedt M., Sun G., Syritski V., Reut J., Volkmer R., Hinrichs K., Rappich J. Acta Biomater. 2013, 9, 5838-5844.

3. Samanta D., Sarkar A. Chem. Soc. Rev. 2011, 40, 2567-2592.

4. Hinnen C., Parsons R., Niki K. J. Electroanal. Chem. 1983, 147, 329-337.

5. Reed D.E., Hawkridge F.M. Anal. Chem. 1987, 59, 2334-2339.
6. Biomolecular Films, Design, Function and Application, Surfactant Science Series, Vol. 3 (Rusling J.F., Ed.) New York: Marcel Dekker, 2003.

7. Armarego W.L.F. Purification of Laboratory Chemicals, New York: Elsevier, 2009.

8. Solovieva S.E., Muravev A.A., Zakirzyanov R.T., Latypov Sh.K., Antipin I.S., Konovalov A.I. Macroheterocycles 2012, $5,17-22$

9. Solov'eva S.E., Murav'ev A.A., Latypov Sh.K., Antipin I.S., Konovalov A.I. Dokl. Chem. 2011, 438, Part 2, 170-174

10. Petty M.C. Langmuir-Blodgett Films. An Introduction, Cambridge: Cambridge Univ. Press, 1995, pp. 39-46.

11. Solovieva S.E., Tyuftin A.A., Muravev A.A., Gruner M., Habicher W., Korobko S.V., Voloshin Y.Z., Antipin I.S., Konovalov A.I., Bubnov Y.N. Polyhedron 2013, 50, 90-100.

12. Muravev A.A., Solovieva S.E., Latypov S.K., Antipin I.S., Konovalov A.I. Phosphorus, Sulfur, Silicon Relat. Elem. 2013 188, 499-502.

13. Solovieva S.E., Rovnova T.A., Latypov Sh.K., Voloshin Y.Z., Antipin I.S., Konovalov A.I. Phosphorus, Sulfur, Silicon Relat. Elem. 2013, 188, 503-506.

14. Rüdiger V., Schneider H.-J., Solov'ev V.P., Kazachenko V.P., Raevsky O.A. Eur. J. Org. Chem. 1999, 8, 1847-1856.

15. Choe J.-I., Chang S.-K., Nanbu Sh. Bull. Korean Chem. Soc. 2002, 23, 891-895.

16. Ludwig R., Dzung N.Th.K. Sensors 2002, 2, 397-416.

17. Kang Y., Won D.-J., Kim S. R., Seo K., Choi H.-S., Lee G., Noh Z., Lee T. S., Lee Ch. Mater. Sci. Eng. C 2004, 24, 4346 .

18. Wasserman S.R., Biebuyck H., Whitesides G.M. J. Mater. Res. 1989, 4, 886-892

19. Park T., Kang H., Kim Y., Lee S., Noh J. Bull. Korean Chem. Soc. 2011, 32, 39-40.

20. Tyuftin A.A., Solovieva S.E., Muravev A.A., Polyantsev F.M., Latypov Sh.K., Antipin I.S. Russ. Chem. Bull., Int. Ed. 2009, $58,145-151$

21. Csokai V., Grun A., Bitter I. Tetrahedron Lett. 2003, 44, 46814684.

22. Dermody D.L., Crooks R.M., Kim T. J. Am. Chem. Soc. 1996 118, 11912-11917.

23. Shahgaldian P., Sciotti M. A., Pieles U. Langmuir 2008, 24, $8522-8526$.

24. Liu F., Lu G.-Y., He W.-J., Liu M.-H., Zhu J.-G. Thin Solid Film 2002, 414, 72-77.

25. Mel'nikova N.B., Kochetkov E.N., Solov'eva S.E., Popova E.V., Antipin I.S., Bol'shakova A.E., Zhil'tsova O.E., Konovalov A.I. Russ. Chem. Bull., Int. Ed. 2011, 60, 19481955. 